\title{
Planning Framework Options for The Massachusetts Ocean Plan
}

June 9, 2009

Prepared by:

The UMass Boston Planning Frameworks Team and The Massachusetts Ocean Partnership

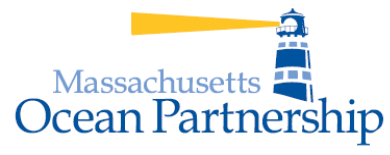




\section{Acknowledgements}

Contributors:

University of Massachusetts Boston

Urban Harbors Institute: Jack Wiggin, Kristin Uiterwyk, Steve Bliven, Dan Hellin

Environmental, Earth and Ocean Sciences Department: John Duff, David Terkla, Bob Bowen

MRAG Americas, Inc.: Andrew A. Rosenberg, Jennie Harrington, Jill H. Swasey, Suzanne ludicello, Robert O'Boyle

Woods Hole Oceanographic Institution Marine Policy Center: Porter Hoagland, Hauke L. KitePowell, Di Jin

Good Harbor Consulting: Fara Courtney

Provincetown Center for Coastal Studies: Rich Delaney, Pat Hughes

University of Rhode Island Marine Affairs Department: Tracey Morin Dalton

Suzanne Goulet Orenstein

Ocean Visions: Charles N. Ehler, Fannie Douvere

Boston University Marine Program: Les Kaufman

Charles T. McCaffrey, Jr.

Massachusetts Ocean Partnership: Nicholas Napoli, Stephanie Moura, Kim Starbuck 


\section{Introduction}

The Massachusetts Oceans Act (Chapter 114 of the Acts of 2008) places the ocean waters and ocean-based development within the ocean management planning area (Ch. 114, Sec. $4 \mathrm{C}(\mathrm{b}))$ under the oversight, coordination, and planning authority of the Secretary of Energy and Environmental Affairs (Secretary) (Ch. 114, Sec. 4C(a)).

Ch. 114, Sec. 4C(a) requires the Secretary to develop an integrated ocean management plan (plan) for the ocean management planning area. Upon adoption of the plan, all certificated, licenses, permits and approvals for any proposed structure, uses, or activities in the area subject to the ocean management plan shall be consistent, to the maximum extent practicable, with the plan (Ch. 114, Sec 4C(e)).

The plan does not supersede existing general or special laws or confer rights and remedies in addition to those of existing or special laws (Ch. 114, Sec. 4C(j)).

The Act contains a number of requirements and provisions to guide plan development and implementation. $\mathrm{Ch}$. 114, Sec. $4 \mathrm{C}(\mathrm{a})$ requires the plan to:

(i) set forth the commonwealth's goals, siting priorities and standards for ensuring effective stewardship of its ocean waters held in trust for the benefit of the public;

(ii) adhere to sound management practices, taking into account the existing natural, social, cultural, historic and economic characteristics of the planning areas;

(iii) preserve and protect the public trust;

(iv) reflect the importance of the waters of the commonwealth to its citizens who derive livelihoods and recreational benefits from fishing;

(v) value biodiversity and ecosystem health;

(vi) identify and protect special, sensitive or unique estuarine and marine life and habitats;

(vii) address climate change and sea-level rise;

(viii) respect the interdependence of ecosystems;

(ix) coordinate uses that include international, federal, state and local jurisdictions;

(x) foster sustainable uses that capitalize on economic opportunity without significant detriment to the ecology or natural beauty of the ocean;

(xi) preserve and enhance public access;

(xii) support the infrastructure necessary to sustain the economy and quality of life for the citizens of the commonwealth;

(xiii) encourage public participation in decision-making;

(xiv) and adapt to evolving knowledge and understanding of the ocean environment;

(xv) identify appropriate locations and performance standards for activities, uses and facilities allowed under sections 15 and 16 of chapter 132A. 
Further, of necessity, the plan needs to be scaleable, i.e., a framework that can be implemented in the short-term with limited data and existing authorities, but can evolve through subsequent revisions to become more specific and adapt to incorporate better data, with more specialized decision support tools, and perhaps with enhanced or more finely-tailored authorities.

\section{Planning Framework Options}

The Massachusetts Ocean Partnership (MOP) Planning Frameworks Team, in consultation with the Massachusetts Executive Office of Energy and Environmental Affairs (EEA), and based on collective experience and a review of ocean, coastal and resource management programs from the US and other countries, suggests that the following nine elements are essential components of the framework for the Massachusetts Ocean Plan and its implementation. While management plans and programs generally have these elements in common, there are a range of options for carrying out each program component. These options were presented to structure and inform the development of the Massachusetts Ocean Plan. For the most part, the range of options represents those that were considered to be appropriate under the Commonwealth's existing legal and administrative structure and responsive to the requirements of the Massachusetts Ocean Act. However, the general concepts these options represent are likely to be transferable to other jurisdictions (especially in the United States) and can inform future ocean management and planning in Massachusetts. Additionally, options or their core elements can be combined to create additional alternatives within one of the nine planning components.

\section{Goals/Principles/ObJectives}

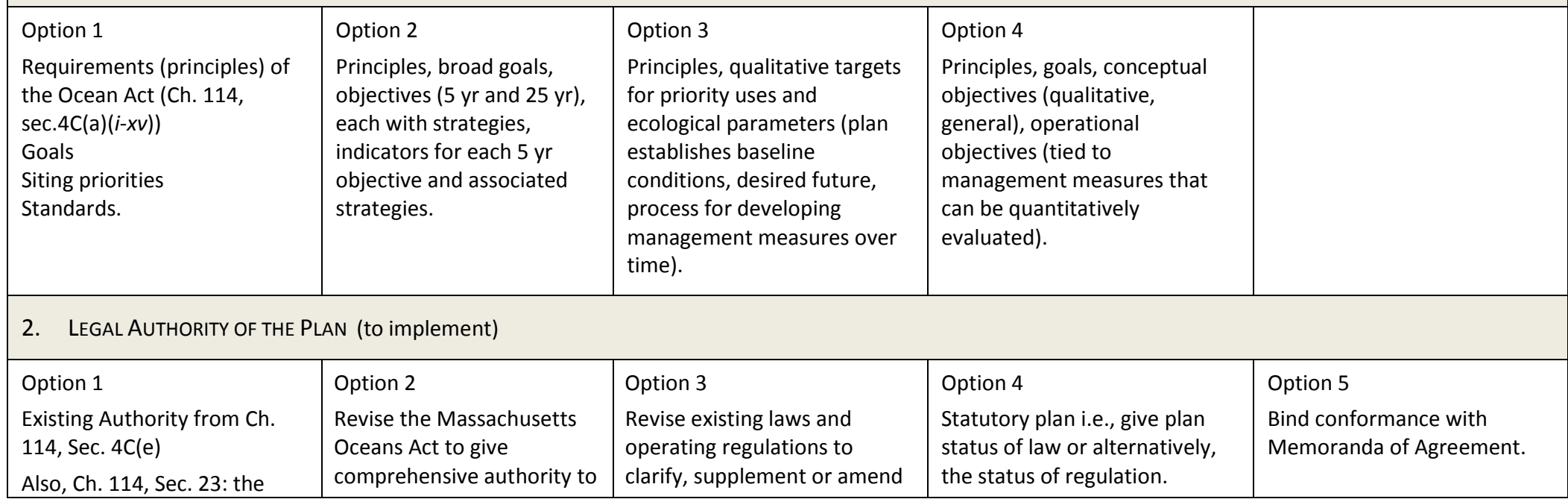


plan shall be incorporated as part of the federallyapproved MCZM program, i.e., implemented and enforced through those authorities. approve or disapprove on case-by-case basis all plans, projects or regulations proposed by any state (or local) authority or private developer. existing authorities and attain

necessary degree of

coordination, cooperation

and conflict resolution

3. ORGANIZATIONAL/INSTITUTIONAL STRUCTURE

\section{Option 1}

Networked: Utilization of existing (and new) authorities that are exercised based on the goals/policies of the Ocean Plan and, taken together, used to implement the management program.

\section{Option 2}

Centralized: A single authority plans and regulates uses subject to

the management program.

\section{Option 3}

Decentralized: All

jurisdictions that exercise authority are consistent with the plan (subject to EEA Secretary review).

\section{Option 4}

Legislation codifies entirely

new, integrated management

structure (e.g. UK Marine Bill) -

creates new authorities,

realigns entire regulatory

structure.

4. INTER-JURISDICTIONAL COORDINATION WITHIN AND OUTSIDE THE OCEAN PLANNING BOUNDARY

Option 1

Employ existing

Massachusetts Coastal Zone

Management (MCZM)

program authorities,

including federal consistency.

(n)

\section{Option 2}

Special Area Management

Plan (SAMP) (Sec 302,

FCZMA). Comprehensive

plan with policies,

standards, criteria, and

implementation

mechanisms to guide

public and private decisions

in specific geographic area;

Federal consistency

provisions of MCZM

program allows extension

to federal waters;

Intergovernmental steering committee.

\section{Option 3}

A Programmatic General

Permit (PGP) is a type of

general permit that is issued

to avoid unnecessary

duplication of regulatory

control exercised by another

federal, state, or local agency.

\section{Option 4}

Comprehensive

intergovernmental agreement.

Option 5

(a) New interagency

Management Network to

improve coordination outside ocean planning boundary.

(b) New binding regional ocean governance structure established.

5. CONTINUING PUBLIC OR STAKEHOLDER INVOLVEMENT

\begin{tabular}{|c|c|c|c|c|}
\hline Option 1 & Option 2 & Option 3 & Option 4 & Option 5 \\
\hline $\begin{array}{l}\text { Continue Ocean Advisory } \\
\text { Council (OAC) established by }\end{array}$ & $\begin{array}{l}\text { Establish Advisory Council: } \\
\text { a core multi-stakeholder }\end{array}$ & $\begin{array}{l}\text { Massachusetts Ocean } \\
\text { Partnership continues this }\end{array}$ & $\begin{array}{l}\text { Rely on public participation } \\
\text { opportunities within existing }\end{array}$ & $\begin{array}{l}\text { Regional advisory committees } \\
\text { supported by Regional }\end{array}$ \\
\hline
\end{tabular}




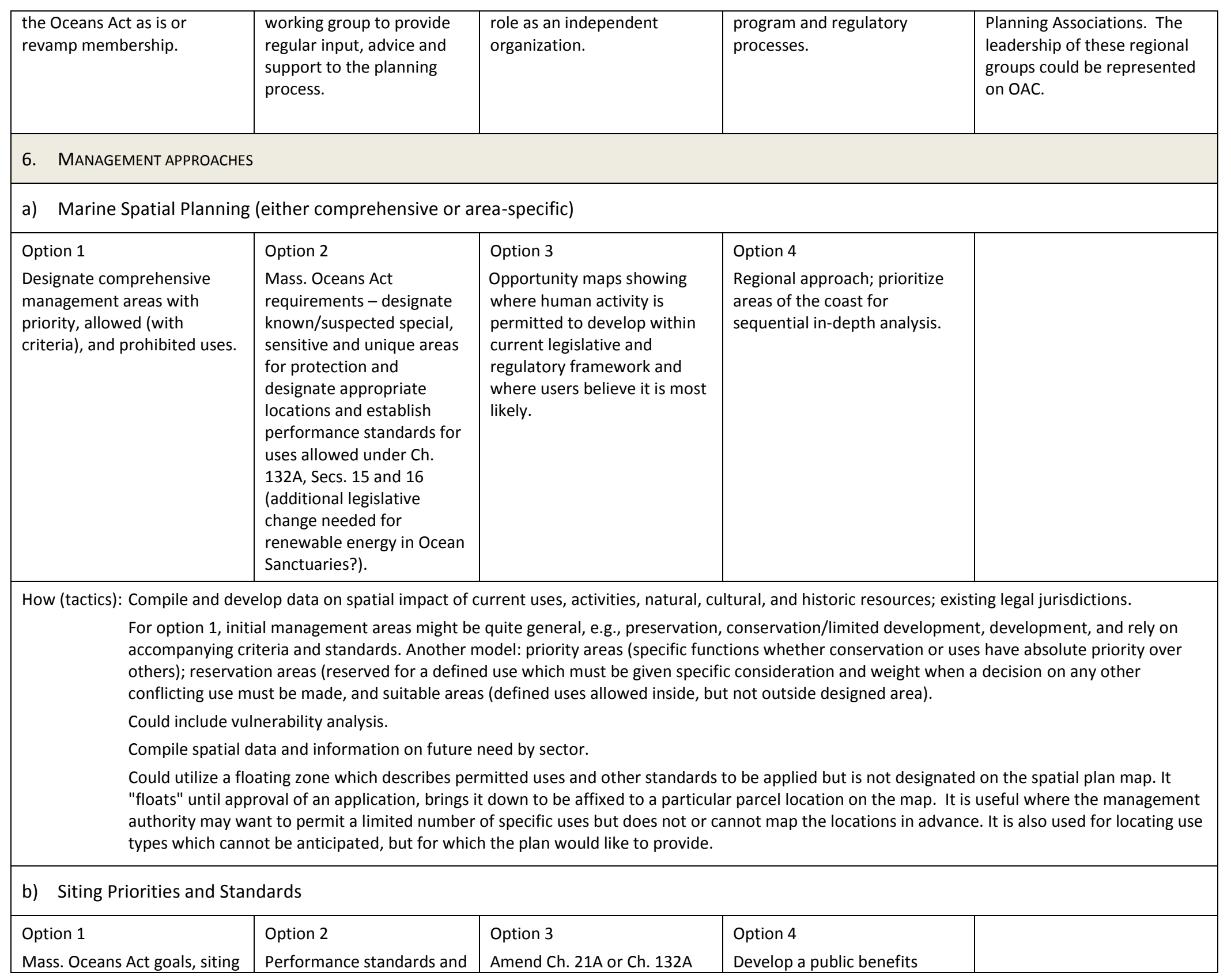


priorities and standards for
effective stewardship Ch. 114 , Sec. $4 C(a)(i)$. guidelines for major uses

based on capabilities and

limitations of resource

types. to provide additional explicit

guidance on priority and

prohibited uses. standard to better and directly

articulate trust values not fully

captured by "fishing, fowling

and navigation", e.g.,

ecosystem services,

biodiversity and climate

change mitigation. Update

Public Trust Doctrine.

How (tactics): (1) use compatibility determination matrix; (2) develop guidelines for resource types and environmental parameters which include ecosystem and human services, priority use, standards for decision making that protect resource values.

\section{FUNDING}

Option 1

Mass. Oceans Act '08: Ocean

Resources and Waterways

Trust Fund (mitigation fees,

appropriations, grants,

investment income).

\section{Option 2}

Statutorily authorize state

and/or federal (CZM

reauthorization)

appropriations.

\begin{tabular}{|c|c|}
\hline Option 3 & Option 4 \\
\hline $\begin{array}{l}\text { Public-private funding } \\
\text { partnership w/ MOP? }\end{array}$ & $\begin{array}{l}\text { Shared cost of baseline data } \\
\text { collection with developers } \\
\text { pursuing priority projects (UK } \\
\text { offshore wind model - all data } \\
\text { in public domain). }\end{array}$ \\
\hline
\end{tabular}

\section{Option 3}

Initial plan should lay out specific staffing and related needs.

\section{Implementation Measures}

a) Promulgate Regulations

\section{Option 1}

Mass. Oceans Act requires promulgation of regulations to implement, administer and enforce [the plan] including review of the plan, baseline assessment, and enforceable provisions every 5 years ( $\mathrm{Ch}$.

114, Sec. $4 \mathrm{C}(\mathrm{h}))$.

\section{Option 2}

Revise existing regulations

as needed, e.g., Ch 91,

MEPA, consistent with the

plan (in addition to

promulgating regulations

regarding plan revisions).

\section{b) Marine Spatial Management}

\begin{tabular}{l|l|l|l}
$\begin{array}{l}\text { Option 1 } \\
\text { Comprehensive marine } \\
\text { zoning, i.e., allowed and }\end{array}$ & $\begin{array}{l}\text { Option 2 } \\
\text { Designate areas/zones for } \\
\text { protection of specific }\end{array}$ & $\begin{array}{l}\text { Option 3 } \\
\text { Designate highly vulnerable } \\
\text { areas for protection. }\end{array}$ & $\begin{array}{l}\text { Option 4 } \\
\text { Designate broad areas for } \\
\text { priority use development, }\end{array}$
\end{tabular}


prohibited uses based on

spatially explicit areas /zones.

resources and priority uses

only. Rely on existing

regulatory programs for

remainder. based on first tier exclusions

(ecological and use). This

requires determining priority uses.

How (tactics): adopt or adapt comprehensive or area-specific marine spatial planning (MSP) (in an integrated ocean management? (IOM) plan) as a regulatory map or as a plan to guide decision making.

\section{c) Siting Priorities and Standards}

Option 1

Ch. 114, Sec. 4C (a)

requirements, goals,

objectives, strategies.

\section{Option 2}

Develop performance

standards for major

activities based on

capabilities and limitations

of resource types.

\section{Option 3}

Amend Ch. 21A or Ch. 132A

to provide additional specific guidance.

9. Program eValuation/adaptation (Plan for Plan 2.0)

\begin{tabular}{|l|l|}
\hline Option 1 & Option 2 \\
Data/tools for plan & Establish consistent \\
development and evaluation & monitoring standards for \\
of plan alternatives. & development activities; \\
& share funding with \\
& developers and manage \\
& information generated in \\
& the public domain. \\
\hline
\end{tabular}

\section{Option 3}

Establish timeframe for development of Quality

Status Reports to track

progress toward goals and

inform adaptive

management/evolution of

management measures.

How (tactics): Conduct studies on current and future economic value of major offshore activities in relation to their spatial use.

EBM science tools useful for spatial planning options.

Spatial monitoring and permit tracking system: up-to-date snapshots of current and anticipated uses. Track who has issued permits, for how long, for what area (see the Integrated Management Plan for the North Sea; Netherlands).

Integrated (spatial) assessment framework for issuing permits: each activity requiring a permit will need an assessment of the choice of location and efficiency in the use of space (see the Integrated Management Plan for the North Sea; Netherlands).

Develop alternative scenarios for future use of ocean space, including adaptation strategies for climate change.

Use of indicators to measure progress and success.

Great Barrier Reef Marine Park Authority (GBRMPA) - Representative areas program: a network of highly protected areas that is representative of all 70 bioregions (habitats) within the planning area. 


\section{Discussion of the Core Components}

The following material expands upon several of the key planning framework elements presented above in matrix format. Explanatory material was developed for four of the nine framework elements (\#3-\#6 from the Planning Framework Options matrix) that were of primary interest in the initial stages of developing the Massachusetts Ocean Plan. These elements are (A) organizational/institutional structure, (B) interjurisdictional coordination within and outside the ocean planning boundary, (C) continuing public or stakeholder involvement, and (D) management approaches. Explanatory material will be developed for the remaining elements as it is needed for refinement of the plan.

\section{A. Organizational/Institutional Structure}

\section{Options}

1. Networked

Utilization of existing (and new) authorities that are exercised based on the goals/policies of the Ocean Plan and, taken together, used to implement the management program

Definition:

A networked program typically has a centralized entity for planning, policy development, coordination, technical and funding assistance, etc. with implementation of programs being performed in other authorities (generally already-existing permitting and/or licensing authorities). Memoranda of Agreement/Understanding are often utilized to ensure consistency in policy between and among the involved entities.

\section{Advantages for the Massachusetts ocean planning process:}

The establishment of a networked program avoids the creation of a new, centralized program and major changes in statutory/regulatory programs. Having a centralized planning/policy office located in or near a Secretarial level office ensures that the policies of the Executive branch are clearly transmitted to implementing agencies. Providing technical and funding assistance offers the opportunity to address new and emerging issues and rapidly offers solutions to the administration and the implementing agencies.

Disadvantages for the Massachusetts ocean planning process:

While this system often works well initially, over time and due to new political administrations, the original role of the planning/policy entity may change or be diminished leading to a loss in effectiveness. [We saw this happen in New Jersey where the networked coastal management program almost disappeared at one point.] Additionally, there can be difficulties in communication and/or administrative "turf" issues between the planning/policy entity and implementing agencies.

\section{Tools for Implementation:}

Establishment through legislation of the centralized planning/policy entity and clear memoranda of understanding/agreement citing goals of the Massachusetts Ocean Plan could form the basis for a networked program.

Examples of networked programs in use: 
The Massachusetts Coastal Zone Management Program, and those of most other states, are examples of networked programs.

2. Centralized single authority plans and regulates uses subject to the management program Definition:

A centralized program has all (or at least most) elements related to management of a particular resource or resource area within one administrative entity. This would include planning and policy development, funding and technical assistance, regulatory programs and administration of areas within state "ownership" (e.g., the seafloor).

Advantages for the Massachusetts ocean planning process:

Centralization brings all of the programmatic elements together under one administrative program. Communication and control is simplified. It results in an agency, or agency subdivision, with a single focus and avoids potential management by resource type (as opposed to comprehensive management of a group of resources within a specified management area.)

Disadvantages for the Massachusetts ocean planning process:

To establish a centralized program would require the establishment of another agency or agency subdivision and reworking of several statutes, regulatory and non-regulatory programs. It is probable that this would be considered "another layer of bureaucracy"; something that was strenuously avoided with the founding of the existing Massachusetts Coastal Zone Management Program.

Tools for Implementation:

This would require reworking statutory and regulatory language within several resource management programs to function within a single office. This might be beneficial in terms of comprehensive management but would be time-and effort-consuming.

Examples of centralized programs in use:

The California Coastal Commission and the Rhode Island Coastal Resources Management Council are examples of centralized programs.

\section{B. Inter-jurisdictional Coordination within and outside the Ocean Planning Boundary}

Options

1. Employ existing Massachusetts Coastal Zone Management (MCZM) program authorities, including federal consistency.

Definition:

The Massachusetts Coastal Zone Management Program (MCZMP) is defined in both statute and regulation. It functions using a networked system with the Coastal Zone Management Office providing program and policy direction and coordination and implementation by various other agencies. The program includes the federal consistency process in which federal agencies are bound to act consistently with the program policies of the MCZMP "to the maximum extent practicable." Local governments function consistently with the 
MCZMP in their administration of the state Wetlands Protection Act (by Conservation Commissions), through the implementation of state standards for mooring and anchorage programs (by Harbormasters), and implementation of state fishery management programs (through Shellfish Officers and Herring wardens).

\section{Advantages for the Massachusetts ocean planning process:}

The inter-jurisdictional programs mentioned above are already in existence and have been tested over the years. Minor adjustments might need to be made to apply some of the aspects to marine waters (e.g., the Commonwealth might consider amending the Wetlands Protection Act to remove local jurisdiction seaward of the management boundary line defined for Massachusetts Ocean Plan and ceding jurisdiction for these waters to the Department of Environmental Protection (DEP)).

\section{Disadvantages for the Massachusetts ocean planning process:}

Most of the tools currently in use are "generic" in that they typically address specific resource management issues as though they are the same throughout the ocean plan area. Local governments have created local wetlands protection bylaws to focus more closely on specific types of resources and activities. The existing state programs do not have this advantage.

\section{Tools for Implementation:}

As mentioned above, the tools for this form of management are already in place, although perhaps it would be beneficial to provide mechanisms for greater focus in specified geographic areas or types of resources. Federal consistency provides a tool for managing interactions with the federal government. For the limited area abutting the New Hampshire border to the north, Memoranda of Understanding/Agreement could be developed as needed to ensure consistency of management.

This, or any other, option adopted should include a review of existing and new federal laws and policies that provide states with input regarding federal waters issues above and beyond the consistency voice provided CZMA (e.g., Section 8(g) of the OCSLA (43 USC Sec $1337(\mathrm{~g}))$ which provides states with royalty benefits from oil and gas drilling where the drilling takes place beyond state waters but within the immediately adjacent three mile band of federal waters.)

Examples in use: The MCZM program provides an example of how such a system could work.

2. Special Area Management Plan (SAMP) (Sec 302, FCZMA).

Comprehensive plan with policies, standards, criteria, and implementation mechanisms to guide public and private decisions in specific geographic area. Federal consistency provisions of MCZM program allows extension to federal waters. Includes an intergovernmental steering committee.

\section{Definition}

Within the federal Coastal Zone Management Act, a SAMP is defined as follows: "...a comprehensive plan providing for natural resource protection and reasonable coastaldependent economic growth containing [1] a detailed and comprehensive statement of policies; [2] standards and criteria to guide public and private uses of lands and waters; and 
[3] mechanisms for timely implementation in specific geographic areas within the coastal zone." (16 U.S.C. § 1453. Definitions (Section 304)) [Numbering added]

As implemented to date nationally, SAMP boundaries vary widely, developed waterfront or port areas (e.g., New York Local Waterfronts); significant resource areas (e.g., the New Jersey Hackensack Meadowlands); portions of, or whole water bodies such as embayments, estuaries, or rivers (e.g., Pleasant Bay, MA); or defined marine resources (e.g., a coral reef habitat or a marine sanctuary).

Advantages for the Massachusetts ocean planning process:

SAMPs allow for particular focus and coordination within defined areas of particular importance in coastal management. The federal Office of Ocean and Coastal Resource Management (OCRM) offers funding and technical assistance in their development, assuming they meet the standards of the Coastal Zone Management Act. They can be used to refine general management policies to protect specific interests, better coordinate the policies of various jurisdictions, and better address cumulative and secondary impacts.

Disadvantages for the Massachusetts ocean planning process:

SAMPs work best in specific, localized areas and when focused on specific interests. As such, they might be ideal for particular portions of the Massachusetts planning area, but might become too "diluted" if applied to the entire planning area. They are time-intensive to develop, particularly if they are to become part of the state coastal management program as approved by NOAA.

\section{Tools for Implementation:}

SAMPs can either utilize existing implementation mechanisms, provide special nonregulatory emphasis for funding and/or technical assistance, or new regulatory_standards can be created that apply only within the boundaries of the SAMP.

\section{Examples of SAMPs in use:}

The Management Plan for the Pleasant Bay (MA) Area of Critical Environmental Concern gives a good example of both the planning process and implementation through coordinated local efforts. The State of Rhode Island has developed SAMPs for the salt pond area along its southern shore, various watersheds, an area along the edge of Aquidneck Island and Greenwich Harbor. Thus far, no SAMPs for open water area have been submitted to OCRM for approval but the management plans for Marine Sanctuaries and Marine Protected Areas may provide a model.

3. Programmatic General Permit (PGP)

A PGP is a type of general permit that is issued to avoid unnecessary duplication of regulatory control exercised by another federal, state, or local agency.

Definition:

A Programmatic General Permit (PGP) is a type of general permit issued by the US Army Corps of Engineers "to avoid unnecessary duplication of regulatory control exercised by another federal, state, or local agency. With a PGP, a permit applicant generally must only apply to one agency rather than applying to both agencies for permits for the same work." (www.swf.usace.army.mil/pubdata/environ/regulatory/permitting/gp.asp) 
General Permits of any sort typically include terms and conditions for compliance and may require preconstruction notification of the U.S. Army Corps of Engineers (See 33 CFR 320.1 (c), $322.2(f), 323.2(h), 325.2(e)(2)$, and 330).

Advantages for the Massachusetts ocean planning process:

The establishment of a PGP would improve consistency in regulatory decision-making between the federal and state agencies and simplify the process for applicants.

Disadvantages for the Massachusetts ocean planning process:

The PGP process typically does not include local governments, has limited interactions in areas or subjects outside of the jurisdiction of the Corps, and has limited impact on nonregulatory issues.

Tools for Implementation:

A PGP would have to be developed between the Corps, other federal agencies, and state agencies. This would be reviewed by the state through the federal consistency process administered by the MCZM program.

Examples of PGPs in use:

There is a PGP in effect in Massachusetts for activities considered to have "minimal impacts" under the provisions of Section 404 of the Clean Water Act, Section 10 of the Rivers and Harbor Act of 1899, and Section 103 of the Marine Protection, Research and Sanctuaries Act within the wetlands and waters of the Commonwealth of Massachusetts. The PGP results in an expedited permit review process.

\section{Continuing Public or Stakeholder Involvement}

Options

1. Ocean Advisory Commission (OAC)

The OAC was established by the Massachusetts Oceans Act to assist the Secretary of EEA in developing the ocean management plan. The composition of the commission is specified in the Act to ensure representation from the legislative and executive branches of state government, a range of ocean users, and the regions of the Massachusetts coast. The OAC is charged with holding public meetings relative to the ocean management plan and making recommendations to the Secretary. The legislation does not appear to give the OAC a role in the implementation of the ocean management plan. Using the OAC as a mechanism for continuing public/stakeholder involvement during plan implementation might require new legislative authorization and its membership may need to be revamped to better serve this new purpose.

2. Establish an Advisory Council (a core multi-stakeholder working group to provide regular input, advice and support to management plan implementation).

An important element of stakeholder involvement is to provide a meaningful role for them in the planning process. There are examples both within and outside Massachusetts of stakeholder involvement in which interested citizens and/or representative stakeholders are appointed and/or elected to serve in an advisory capacity. Massachusetts examples include 
the Marine Fisheries Commission and Cape Cod and Martha's Vineyard commissions. Relevant examples from other states include the North Carolina Coastal Resources Commission and the Rhode Island Coastal Resources Management Council. While they have regulatory authority, these commissions and councils also have significant policymaking and strategic planning responsibilities.

An EEA Advisory Council with broad stakeholder representation and responsibilities that might include reviewing proposed activities and developing recommendations on consistency with the ocean management plan prior to agency permitting; providing advice on implementation of short and long-term priorities and monitoring the integration of current scientific and technical information into the plan implementation process, could provide meaningful stakeholder engagement in the refinement and implementation of the plan.

3. Massachusetts Ocean Partnership continues this role as an independent organization.

The Massachusetts Ocean Partnership is a broadly representative, independent publicprivate partnership created specifically to advance ecosystem-based integrated multi-use management of the Commonwealth's coastal ocean waters. MOP has had significant supportive roles in the development of the state's ocean management plan contributing technical assistance, the perspectives and expertise of its membership, and supporting and enhancing the public participation process. The organization's activities are supported with funding from a private foundation. Over the long run, its capacity to continue its stakeholder function will depend on achieving the full breadth of stakeholder interests as the plan evolves and/or continued funding.

4. Rely on public participation opportunities within existing program and regulatory processes.

In general the public participation opportunities within existing program and regulatory processes are often limited to a specific project review or rulemaking. These processes tend to be viewed as something that has to be done, rather than an opportunity to engage citizens in a meaningful discussion of the issues. These opportunities would not satisfy the interests and desires expressed by citizens and stakeholders in the listening sessions and stakeholder interviews.

5. Utilize regional advisory committees

Regional participation and perspectives in ocean management planning and implementation is very appropriate, particularly with regard to evaluating the individual ocean sanctuaries. The Martha's Vineyard and Cape Cod commissions must consider regional impacts of development and both have exercised their jurisdiction in coastal waters. The state might consider collaborating with these and other commissions and regional organizations as an institutional component of any stakeholder arrangement that is ultimately employed. In addition, a newly established Advisory Council or similar entity should consider regionally oriented subcommittees.

The Massachusetts Bays Program utilizes local governance committees to not only identify issues of local and regional significance, but to target implementation efforts and funds, within the context of the management plan. The State of Washington's Northwest Straits program has a regional and a central Commission structure, in which the seven affected 
counties each have a Marine Resources Committee, comprised of a diverse group of stakeholders (See http://www.nwstraits.org/)

\section{Management Approaches}

Marine Spatial Planning (either comprehensive or area-specific)

Since the Act requires Option 2 at a minimum, the steps in Options 1, 3 and 4 are the likely actions that would be taken in an evaluation of each of the ocean sanctuaries.

Options

1. Designate comprehensive management areas with priority, allowed (with criteria), and prohibited uses.

This option would require, at a minimum, a thorough analysis of (1) the resources, (2) the siting and operational requirements of a range of uses, (3) the sensitivity of resources to these uses, (4) compatibility/conflict among uses and (5) development of criteria to be applied to allowable uses based on environmental, operational and social factors.

While not necessarily originally resource-based, the current ocean sanctuaries could be viewed as comprehensive management areas. Canada identified its Eastern Scotian Shelf as one of five priority ocean planning areas (large ocean management areas) and developed an Eastern Scotian Shelf Integrated Management Plan. The Plan does not include specific priority, allowed and/or prohibited uses, but relies on the existing management and regulatory structure to implement the plan. One implementation tool is the designation of marine protected areas. Two have been designated within the Eastern Scotian Shelf region, with prohibitions and restrictions on certain activities (See www.mar.dfompo.gc.ca/oceans/e/essim/plan/essim-plansum-e.html ).

As part of the development of the Barents Sea- Lofoten Islands integrated management plan, Norway identified and mapped the approximate extent of particularly valuable and vulnerable areas. They developed criteria for determining environmental vulnerability and this work, along with additional impact assessments, led to prohibitions on future oil and gas development in some areas and recommendations for changes in fishing activity and areas where fishing is allowed (See www.regieringen.no/Upload/MD/Vedlegg/Svalbard\%20og\%20polaromraadene/Forvaltning splan\%20Barentshavet/PDF0080506 engelsk-TS.pdf)

2. The Massachusetts Oceans Act requires, as a minimum: Designate known/suspected special, sensitive and unique areas for protection and designate appropriate locations and establish performance standards for uses allowed under Ch. 132A, secs. $15 \& 16$

The process leading to these designations likely would be similar to that outlined in Option 1. Use designations might involve a finding of overriding public benefit (or "public necessity and convenience") to allow for some level of environmental degradation and/or loss of use, i.e. designating sand source sites for beach nourishment or to provide for areas of scientific research.

As noted above, the existing Ocean Sanctuaries could be treated as management areas in which some activities are prohibited or allowed with conditions. Individual management plans and possibly implementing regulations for each of the Ocean Sanctuaries could benefit 
the state and affected regions, through designating special areas and identifying priority uses and opportunity areas. While the Ocean Sanctuaries may share some similar resources and environmental conditions, each sanctuary has resource values and conditions special to it. Additionally, economic and public opportunities vary in each of the sanctuaries.

The plan/regulations might include specific criteria that must be met for the state to make a finding of "public necessity and convenience". This process is likely to include the analyses described under Option 1 and 2, as well as a mapping effort similar to Option 4.

The Great Barrier Reef World Heritage Area Strategic Plan identifies 8 zones in which certain activities are allowed, conditioned or prohibited, dependent on the purpose of the zone. One of the aims of the plan is "to protect the natural qualities of the Great Barrier Reef Marine Park, while providing for reasonable use" (See www.gbrmpa.gov.au/ data/assets/pdf file/0005/2111/mp 017 full.pdf).

The Netherlands established a system of ecological targets for all typical Wadden Sea habitats in the management plan. All targets are conservation-focused; other uses are addressed primarily in terms of limiting ecosystem impacts from them (specifies that navigational safety and requirements for coastal protection will take precedence where necessary, and there are areas where specific human use takes priority (See www.waddensea-secretariat.org/management/Plan.html)).

3. Opportunity maps showing where human activity is permitted to develop within current legislative and regulatory framework and where users believe human activity is most likely occurring.

A solid amount of information to support such a map was compiled in the working groups and presented in a collection of figures included in each of the group reports. This option would likely be one part of a more comprehensive management plan effort.

4. Regional approach; prioritize areas of the coast for sequential in-depth analysis Again, the existing ocean sanctuaries could be viewed as priority management areas of regional significance. Their boundaries were not ecologically determined and similar resources, habitats and oceanographic conditions are present in more than one. Determining priority among the five ocean sanctuaries would likely require developing review criteria and significant public involvement. There may be economies of scale in conducting in-depth analyses of each concurrently, with regional and state participation.

\section{$\underline{\text { Siting Priorities and Standards }}$}

\section{Options}

1. The Massachusetts Oceans Act's goals, siting priorities and standards for effective stewardship- 4C (d)(i)

As these are required to be considered in the ocean plan, they could be viewed as the goals of the plan. In most every ocean management plan that has been evaluated by the Planning Frameworks team, the goals were further refined to include objectives and, in some plans, performance indicators.

2. Performance standards and guidelines for major uses based on capabilities and limitations of resource types 
Massachusetts currently uses this approach in its environmental permitting. Examples include the Wetlands Protection Act (310 CMR 10.00) and the Waterway regulations (310 CMR 9.00). In the Wetlands Protection Act (WPA) activities affecting specific resource areas are regulated in order to contribute to specific interests, including prevention of pollution, protection of land containing shellfish and protection of fisheries. ${ }^{i}$

3. Amend Chapter $21 \mathrm{~A}$ or Chapter $132 \mathrm{~A}$ to provide additional explicit guidance on priority and prohibited uses

See the discussion under Option 3 under Marine Spatial Planning above.

Tactics

Compatibility Determination

A decision process needs to be established to determine how the ocean and its resources should be used and/or protected. A main driver in making such decisions will be an examination of the compatibility or incompatibility of various uses not only with other uses, but also with the goals and objectives established in the ocean plan. There are many ways to construct this decision process, as outlined below.

A review of how other programs decide where/how to site ocean uses reveals some distinct methods. One approach is to develop or utilize a "decision support tool." Another approach is to prepare a management plan and require decisions to be consistent with that plan's goals, objectives, and policies. Additionally, one might develop a marine spatial plan (based on goals and objectives, existing uses, public input, etc.) identifying what can and cannot happen in specific areas. Hybrids of the above are also possible.

Options

1. Decision Support Tools

Developed and used correctly, a tool can provide a useful process and structure for examining and evaluating ocean uses. Depending on the goals and objectives of the Massachusetts Ocean Plan, decision makers can opt to use one of (or a series of) the tools presented in the MOP commissioned paper "Science Tools to Implement Ecosystem Based Management in Massachusetts" ("Science Tools").

In thinking about how to use a tool, it is helpful to look at an example from Stellwagen Bank National Marine Sanctuary. While writing the draft management plan, a working group for the Sanctuary recommended a strategy for developing the framework to determine compatibility, which included developing a screening tool. Within their strategy, they:

a) Suggested a hierarchical approach to developing the framework for compatibility determination

b) Noted the importance of first having a vision, goals, and objectives

c) Once (a) and (b) have been addressed, recommended developing a screening tool to answer specific questions about whether or not a use is compatible. This tool should consider existing regulations, risk analysis, cumulative impact assessment, best available data, and public input (note that their screening tool recommends the use of other tools in its development). Additionally, this tool should decide if certain stipulations could make a use compatible. Finally, this tool should include measurable indicators and 
standards to detect the effects of compatible uses and determine if those effects meet the standards of compatibility

d) Once (a) through (c) have been completed, update the screening tool as needed given new information

Massachusetts has also been exploring the idea of using a tool (a matrix) to determine compatibility. 
Working matrix for Massachusetts

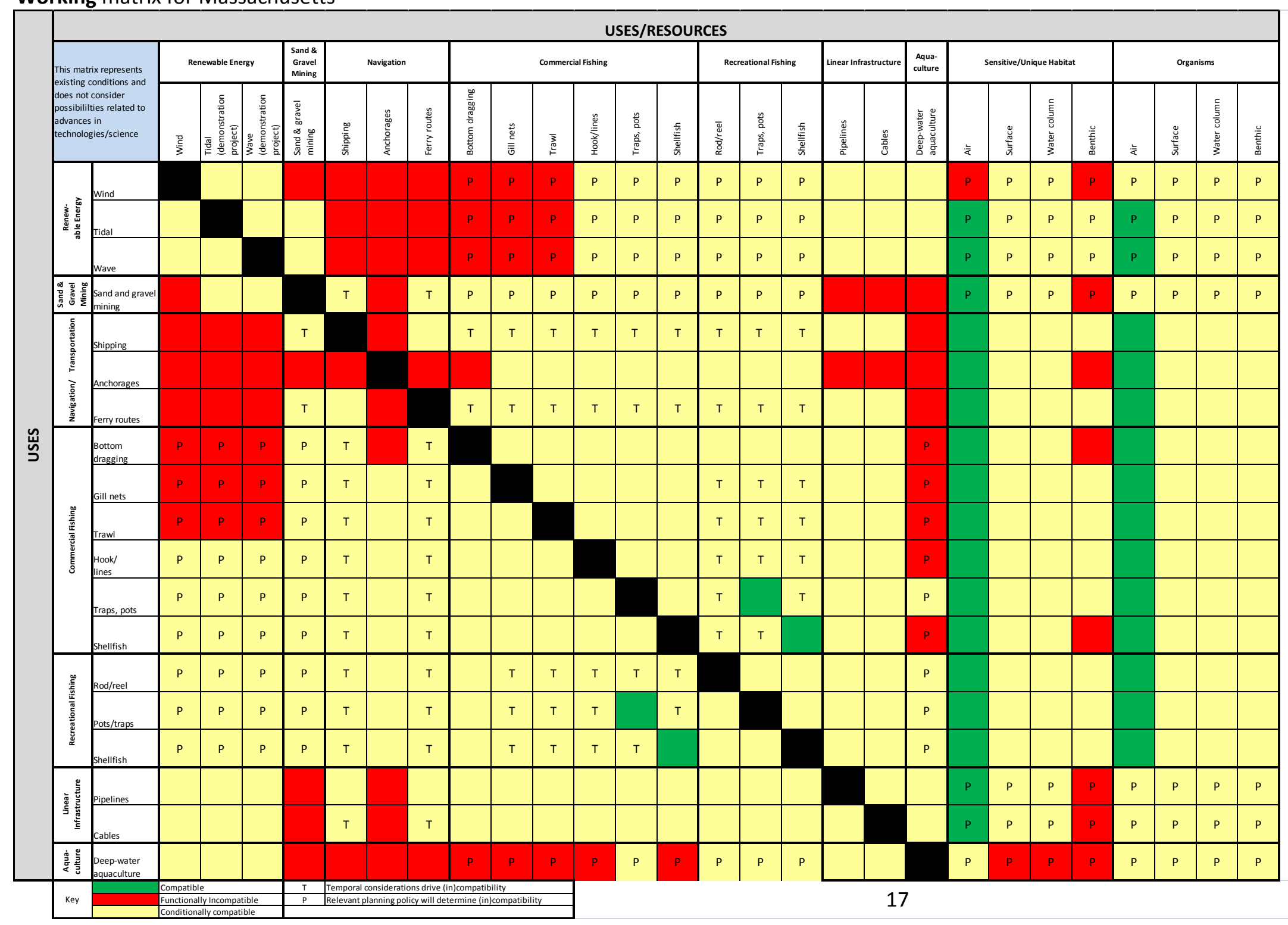


Still a work in progress, the matrix identifies uses that are compatible or incompatible with other uses and resources. The matrix also identifies instances where uses might be compatible with other uses or resources. These "conditionally compatible" situations will require further analysis before a decision can be made. While some of the conditionally compatible situations are simply temporal in nature, others are more complex and might benefit from a tiered evaluation process (See box below) that can be facilitated and/or informed by using one or several of the decision support tools identified in the MOP Science Tools paper.

\section{TIERED EVALUATION PROCESS:}

1. Is the proposed use/project consistent with the plan's goals and objectives?

a. Yes. - continue to question \#2

b. Somewhat (goals and objectives might conflict) - continue to question \#2 (unless goals are prioritized, etc. and there is some way to make a valid "no" decision)

c. No.

i. Is there some pressing reason why the use should be considered anyway (i.e. homeland security, new technology, necessary research, etc.)?

1. Yes - go to question \#2

2. No - Project/use not allowed without appropriate revisions

2. Can this use happen within the planning area? (Consider existing rules and regulations and existing conditions/resources)

a. Yes. - Continue to question \#3

b. No.

i. Is there some pressing reason why the use should be considered anyway?

1. Yes - go to question \#3

2. No - Project/use not allowed without appropriate revisions

3. Within the area(s) suitable for this use, is this use compatible with other existing or planned uses?

a. Yes. - Continue to question \#4

b. No.

i. Is there some pressing reason why the use should be considered anyway? (This use is more important than other uses, this is the only place it could happen, conflicts are only temporal in nature, etc.)

1. Yes - go to question \#4

2. No - Project/use not allowed without appropriate revisions

4. Will this activity/project have negative environmental impacts? (Consider cumulative impacts)

a. No. - Continue to question \#5

b. Unknown.

i. Is state willing to approve anyway (consider possibility of monitoring impacts, etc.)

1. Yes - go to question \#5

2. No - Project/use not allowed without appropriate revisions

c. Yes.

i. Is there some pressing reason why the use should be considered anyway? (i.e. State is willing to accept level of impact with appropriate mitigation; impacts are temporary, etc.)

1. Yes - go to question \#5

2. No - Project/use not allowed without appropriate revisions

5. Is there any other reason why this use should not be allowed?

a. No. - Project/activity allowed as proposed

b. Yes. - Project/use not allowed without appropriate revisions 
Within the tiered evaluation process, decision makers would have to make additional choices such as whether or not to allow a use with unknown impacts, whether or not some uses have priority over other uses, etc. Nevertheless, this tiered approach provides a method for considering uses as they relate to goals and objectives, existing rules and regulations, other uses, available natural resources, and potential impacts.

While a tool can be used by itself to help guide decisions, a tool can also be part of a larger process that leads to marine spatial planning.

2. Marine Spatial Planning (MSP)

Successful MSP is time and labor intensive, involving considerable research, data management, mapping, and public participation. According to the Handbook on Integrated Maritime Spatial Planning (available online at:

http://plancoast.eu/files/handbook_web.pdf), spatial planning might not be necessary if the planning area is without conflicts or if the resources do not exist to plan effectively. Before beginning the MSP process, the Handbook suggests a process to determine if MSP is necessary:

a) Decide which precise area you want to consider. Is it geographically delineated or does it have administrative boundaries? If necessary, adjust to a different scale and spatial dimension.

b) Take stock of the coastal and marine environment subject to management Consider:

- the coastal and marine ecosystem: what are the particular characteristics?

- the socio-economic system that depends on using coasts and seas

- the current political and institutional context

- the current drivers that might lead to spatial impacts or changing pressures of use.

Early indications for IMSP: sensitive and/or fragile ecosystems, large scale uses, rapid changes to the socio-economic or political system (strong drivers)

A key output of this stage could be a series of maps showing current patterns of use.

c) Assess the trends of use and resulting pressures and spatial threats on the coast and in the sea.

Consider both intensity and diversity of uses

intensity and diversity of uses increases..... > indication for MSP

intensity and diversity of uses stable.......... > MSP may not be needed

intensity and diversity of uses decreases.... > MSP may not be needed 
A key output of this stage could be an additional series of maps showing specific pressures, land-sea interchanges or degrees of vulnerability.

d) Assess the spatial impact of current and likely future uses and the spatial conflicts that might arise

spatial impact likely to increase................ > indication for MSP

spatial impact stays the same................... > MSP may not be needed

spatial impact decreases........................... > MSP may not be needed

spatial conflicts set to intensify................. > indication for MSP

spatial conflicts set to remain the same..... > indication for MSP*

spatial conflicts set to decrease

$>$ MSP may not be needed

*if conflicts are already problematic

e) Decide, based on the above, whether MSP is needed at this stage or not.

Should Massachusetts decide to do a marine spatial plan, it is important to remember that MSP is not a linear process. Financial constraints, data limitations, changing environmental conditions, and the political environment are some of the issues that might impact the MSP process.

One example of MSP can be found at the Great Barrier Reef. The Great Barrier Reef Marine Park Authority's (GBRMPA) main purpose for establishing its zoning plan was to protect representative areas of the system while still allowing for human uses where appropriate.

The GBRMPA worked with several different entities to pull together data on the natural resources and human uses within the planning boundary. Using that data, the GBRMPA developed a series of draft zones. After a great deal of public input and plan revisions, the final product allows for recreational activities, commercial activities, traditional uses, research, and other uses while simultaneously setting aside areas for conservation and protection. This is accomplished via the creation of eight zones:

1) General Use Zone - "To provide for the conservation of areas of the Marine Park, while providing opportunities for reasonable use". ii Some permissible activities include low impact recreational activities not involving the taking of plants, animals, or marine products; fishing or collecting; traditional uses of marine resources; photography, filming, or sound recording; limited impact research; limited educational programs; navigating a non-managed vessel or aircraft with fishing/collecting gear stowed. Permitted exceptions apply.

2) Habitat Protection Zone - "To provide for the conservation of areas of the Marine Park through the protection and management of sensitive habitats, generally free from potentially damaging activities" and "to provide opportunities for reasonable use." iii Permissible uses are very similar to those in a General Use Zone. Permitted exceptions apply.

3) Conservation Park Zone - "To provide for the conservation of areas of the Marine Park" and "to provide opportunities for reasonable use and enjoyment, 
including limited extractive use. ${ }^{\text {iv }}$ Uses are similar to those in the General Use and Habitat Protection Zones, but also include the taking of aquarium fish, coral fish, and worms in an accredited harvest fishery. Permitted exceptions apply.

4) Buffer Zone - -"To provide for the protection of the natural integrity and values of areas of the Marine Park, generally free from extractive activities" and "to provide for opportunities for (i) certain activities including the presentation of the values of the Marine Park, to be undertaken in relatively undisturbed areas; and (ii) trolling for pelagic species." ${ }^{\prime \prime}$ Permissible uses include low impact activities not involving the taking of plants, animals, or marine products; fishing by trolling, traditional uses of marine resources; photography, filming, or sound recording; limited impact research (non-extractive); limited educational programs; navigating a non-managed vessel or aircraft with fishing/collecting gear stowed. Permitted exceptions apply.

5) Scientific Research Zone - "To provide for the protection of the natural integrity and values of areas of the Marine Park, generally free from extractive activities" and "to provide opportunities for scientific research to be undertaken in relatively undisturbed areas." allowed in the buffer zone, with the exception of fishing. Research opportunities also differ, with both extractive and non-extractive limited impact research permissible. As with the other zones, permitted exceptions apply.

6) Marine National Park Zone - "To provide for the protection of the natural integrity and values of areas of the Marine Park, generally free from extractive activities" and "to provide opportunities for certain activities, including the presentation of the values of the Marine Park, to be undertaken in relatively undisturbed areas." involving the taking of plants, animals, or marine products; traditional uses of marine resources; photography, filming, or sound recording; limited impact research (non-extractive); limited educational programs; navigating a nonmanaged vessel or aircraft with fishing/collecting gear stowed. Permitted exceptions apply.

7) Preservation Zone - "To provide for the protection of the natural integrity and values of areas of the Marine Park, generally undisturbed by human activities." ${ }^{\prime \text { iii }}$ Uses include limited research, including limited impact research (non-extractive and extractive) that is relevant to and a priority for the management of the Park that cannot reasonably be conducted elsewhere; and for any purpose consistent with the objective but not specifically stated.

8) Commonwealth Island Zone - "To provide for the conservation of areas of the Marine Park above the low water mark", "to provide for use of the zone by the Commonwealth", and "to provide for facilities and uses consistent with the values of the area." ${ }^{\text {ix }}$ Permissible uses include low impact activities, traditional uses, photography, filming, or sound recording, conducting limited educational programs, limited educational programs; navigating a non-managed vessel or aircraft with fishing/collecting gear stowed. Permitted exceptions apply. 
In addition to the above zones, the plan identifies Remote Natural Areas that apply to all or part of a zone, with the objectives of ensuring "that the Area remains in a state that is largely unaltered by works or facilities; and...to provide opportunities for quiet appreciation and enjoyment of the Area." ${ }^{\prime x}$ These areas are not appropriate for motorized water sports.

The zoning plan also sets forth designated areas:

- Shipping Areas - where ships can navigate through the park

- Special Management Areas - parts of the Park having specific management measures (to protect resources, regulate access in heavily used areas, ensure public safety, allow resources to recover, etc.)

- Fisheries Experimental Areas - where scientific research can explore the impacts of line fishing on fish stocks and ecosystems (through the Effects of Line Fishing experiment - which was scheduled to end in 2005)

Unless prohibited by other applicable regulations, an applicant may seek a permit to conduct an activity not explicitly prohibited within a zone.

\section{Consistency}

Another option is to use the plan itself as guidance in deciding how to site uses. In cases where tools and a marine spatial plan are not available, this seems to be the most common method for making decisions. Unless the plan is very detailed however, this strategy often lacks the same level of uniformity as options 1 or 2 in terms of making decisions.

One example of plan consistency can be found in the Sacramento-San Joaqin Delta. There, a management plan was developed to address the entire delta; and each town/county with jurisdiction in the delta is required to comply with the plan in its decision making. More specifically, when a potential project comes up, the town/county must:

a) Comply with existing rules and regulations beyond the Delta Management Plan (Clean Water Act, etc.)

b) Comply with the Delta Management Plan (Some of the Plan's policies are very specific, such as this one from the "Land Use" section of the plan: "P-2. Local government general plans... and zoning codes shall continue to strongly promote agriculture as the primary land use in the Primary Zone; recreation land uses shall be supported in appropriate locations and where the recreation uses do not conflict with agricultural land uses or other beneficial uses, such as waterside habitat. County plans and ordinances may support transfer of development rights, lot splits with no increase in density, and clustering to support long-term agricultural viability and open space values of the Primary Zone. Clustering is intended to support efficient use of agricultural lands, not to support new urban development in the Primary Zone...." (http://www.delta.ca.gov/plan/land.asp)

c) Adopt a series of findings that the proposed development will not result in: 
- wetland or riparian loss;

- degradation of water quality;

- increased nonpoint source pollution or soil erosion, including subsidence or sedimentation;

- degradation or reduction of Pacific Flyway habitat;

- reduced public access, provided that access does not infringe upon private property rights;

- expose the public to increased flood hazards;

- adversely impacts agricultural lands or increase the potential for vandalism, trespass, or the creation of public or private nuisances on private or public lands;

- degradation or impairment of levee integrity;

- adversely impact navigation;

- any increased requirements or restriction upon agricultural practices in the primary zone.

Those who disagree with a decision based on the above requirements can appeal to the Delta Protection Commission

Along the same lines as the Sacramento-San Joaqin Delta process, the decision process used by the Rachel Carson National Wildlife Refuge is based on an analysis of the activity's compatibility with the statute. In this case however, the question is whether or not a use is compatible with goals and objectives of the refuge. This compatibility determination does not consider the relationship between uses.

4. Hybrids

As mentioned above, some decision processes can make use of several different tools. Additionally, other decision processes might be a combination of the options presented in this paper.

For example, the Great Barrier Reef employs a combination of options in its decision making process. In addition to the various zones and their related uses/restrictions, there are other uses prohibited by the Great Barrier Reef Marine Park Act of 1975, including

- The drilling and mining within the park (unless approved for the purpose of "research and investigations relevant to the establishment, care and development of the Marine Park or for scientific research" $\left.{ }^{\prime \prime} \mathrm{i}\right)$;

- The building, assembling or fixing in position of (i) buildings or similar structures; (ii) pontoons or other floating structures; (iii) walkways, mooring facilities or similar structures; or (iv) devices for catching marine animals;

- The operating in one vicinity for more than: (i) 14 consecutive days; or (ii) 30 days in any period of 60 days; of vessels with provision for more than 8 sleeping berths; 
- The carrying out of reclamation works, beach protection works, road building works or any other works;

- The construction of landing areas;

- The construction of farming facilities;

- The conduct of operations in or upon, or the maintenance of: (i) buildings or similar structures; (ii) pontoons or other floating structures; or (iii) walkways, mooring facilities or similar structures;

- The maintenance of any device for catching marine animals;

- The demolition or removal of any: (i) buildings or similar structures; (ii) pontoons or other floating structures; or (iii) walkways, mooring facilities or similar structures ${ }^{\mathrm{xii}}$

- The discharge of waste without the appropriate permissions or exceptions. ${ }^{\text {iii }}$

When thinking about whether or not a use is compatible in the Great Barrier Reef, decision makers must not only look at the provisions of the zoning plan, but also the language in the Great Barrier Reef Marine Park Act of 1975 (and any other relevant legislation).

Notes

Section 6.B.

iThe preface to the 1983 regulatory revisions to the Wetlands Act states: "Other than minor changes in format, however, no revisions have been made to Part II, Additional Regulations for Coastal Wetlands, 310 CMR 10.21 et seq. In the Department's judgment, the Part II regulations have worked well, so much so that their salient elements - e.g., the use of presumptions of significance and performance standards - have been incorporated in Part III" (www.mass.gov/dep/service/regulations/310cmr10b.pdf, page 30)

Section 6. Tactics

ii Great Barrier Reef Marine Park Zoning Plan 2003. p.16. On line at: http://www.gbrmpa.gov.au/_data/assets/pdf_file/0016/10591/Zoning_Plan.pdf

iii Great Barrier Reef Marine Park Zoning Plan 2003. p.18. On line at: http://www.gbrmpa.gov.au/_data/assets/pdf_file/0016/10591/Zoning_Plan.pdf iv Great Barrier Reef Marine Park Zoning Plan 2003. p.21. On line at: http://www.gbrmpa.gov.au/_data/assets/pdf_file/0016/10591/Zoning_Plan.pdf

${ }^{v}$ Great Barrier Reef Marine Park Zoning Plan 2003. p.23. On line at: http://www.gbrmpa.gov.au/_data/assets/pdf_file/0016/10591/Zoning_Plan.pdf

${ }^{v i}$ Great Barrier Reef Marine Park Zoning Plan 2003. p.25. On line at: http://www.gbrmpa.gov.au/_data/assets/pdf_file/0016/10591/Zoning_Plan.pdf

vii Great Barrier Reef Marine Park Zoning Plan 2003. p.27. On line at: http://www.gbrmpa.gov.au/_data/assets/pdf_file/0016/10591/Zoning_Plan.pdf 
viii Great Barrier Reef Marine Park Zoning Plan 2003. p.29. On line at: http://www.gbrmpa.gov.au/_data/assets/pdf_file/0016/10591/Zoning_Plan.pdf

${ }^{\text {ix }}$ Great Barrier Reef Marine Park Zoning Plan 2003. p.30. On line at: http://www.gbrmpa.gov.au/_data/assets/pdf_file/0016/10591/Zoning_Plan.pdf

${ }^{x}$ Great Barrier Reef Marine Park Zoning Plan 2003. p.32. On line at: http://www.gbrmpa.gov.au/_data/assets/pdf_file/0016/10591/Zoning_Plan.pdf

${ }^{x i}$ Section 38 of the Great Barrier Reef Marine Park Act 1975. On line at: http://www.austlii.edu.au/au/legis/cth/consol_act/gbrmpa1975257/s38.html.

xii Section 38(F) of the Great Barrier Reef Marine Park Act 1975. On line at: http://www.austlii.edu.au/au/legis/cth/consol act/gbrmpa1975257/s38f.html xiii Section 38(J) of the Great Barrier Reef Marine Park Act 1975. On line at: http://www.austlii.edu.au/au/legis/cth/consol act/gbrmpa1975257/s38f.html 